\title{
AMERICANS' CONTRIBUTIONS TO CLIMATE CHANGE: OPPORTUNITIES FOR MEETING CARBON TARGETS
}

\author{
Kara M. Kockelman \\ (corresponding author) \\ Associate Professor and William J. Murray Jr. Fellow Department \\ of Civil, Architectural and Environmental Engineering The \\ University of Texas at Austin \\ 6.9 E. Cockrell Jr. Hall \\ Austin, TX 78712 \\ kkockelm@mail.utexas.edu \\ Melissa R. Thompson \\ The University of Texas at Austin \\ thomp652@mail.utexas.edu \\ Charlotte A. Whitehead \\ The University of Texas at Austin \\ charlotteaw@mail.utexas.edu
}

The following paper is a pre-print and the final publication can be

found in Journal of Urban Planning and Development, Vol.137

(2): 91-100, 2011.

\begin{abstract}
Meeting California's 2020 greenhouse gas emissions target will require an average CO2 emissions reduction of approximately $380 \mathrm{lbs}$ per month per person in the U.S. For the typical two-person household, $760 \mathrm{lbs}$ per month can be saved by employing such near-term measures as reducing monthly miles traveled (by auto and aircraft) and altering behaviors related to appliance energy consumption (e.g., employing a smart thermostat, reducing water heater temperature settings, and eliminating phantom loads). Additional long-term savings can be obtained by purchasing more fuel efficient vehicles, reducing home floor area, moving into multi-family housing units with shared walls, and replacing old appliances with energy efficient products. To get a sense of where these strategies exist for individuals and households, this paper quantifies greenhouse gas reductions from these and other household decisions. Upstream and downstream emissions-reductions policies are discussed, including taxation, cap and trade among energy producers, and household-level carbon budgets. Given the variability in U.S. climate zones, the sizable contributions of both upstream and downstream carbon sources, and the variety of electricity generation processes, a combination of policy measures seems warranted, in order to achieve recommended targets in a rapid, equitable, and relatively pain-free manner.
\end{abstract}




\section{MOTIVATION}

Climate change has emerged as one of our planet's top issues, and is increasingly a part of the U.S.'s political and economic agenda. There is considerable evidence that the earth's climate is changing as a result of excess greenhouse gases (GHGs) in the atmosphere. Many nations around the world agree that GHG emissions need to be reduced - and sooner is better (IPCC 2007, Stern 2006). In order to stabilize the concentration of GHGs in the atmosphere, the United Nations Framework Convention on Climate Change (UNFCCC), many European countries, the state of California, and others believe that a reduction of $80 \%$ by 2050 is necessary to prevent the most catastrophic consequences of global warming (Stern 2006). Policy makers and researchers across the globe are now implementing many strategies aimed at lowering emissions. Methods include carbon taxation and trading, with caps or taxes on upstream GHG sources, like oil refineries, electricity generators, and industrial plants. The effects of such policies will be felt at the household level by way of higher prices. The price tag may be worth it: Stern (2006) suggests that the total costs of climate change, if no action is taken, is approximately 5\% of global GDP, while the cost of avoidance is approximately $1 \%$ of GDP.

The United States is lagging many nations on this issue. With the exception of the U.S. and Australia, every developed country in the world ratified the Kyoto Protocol (as described below). In April 2002, the United Kingdom implemented the first economy-wide emissions trading scheme (ETS) in the world, in order to learn valuable lessons about emissions trading and apply these to the European Union ETS. By December 2006, the UK ETS had achieved an emissions reduction of over 7.9 million tons of $\mathrm{CO} 2_{\mathrm{e}}$ (or 1 percent of the UK's total emissions) (DEFRA 2007 and 2008). Are such near-term reductions feasible in the U.S.?

The United States implemented the Acid Rain Program in 1995, with the goal of cutting SO2 emissions, an acid rain contributor, to $50 \%$ of their year-1980 levels (EPA 2007c). This successful program reduced emissions by utilizing a cap and trade scheme and setting two progressively tighter caps for 2000 and 2010. Such experiences suggest that the U.S. is probably capable of implementing a successful carbon cap-and-trade scheme, though sources of CO2 are far more abundant than sources of SO2.

This paper summarizes key GHG policies and emissions targets, considers how households might respond to higher energy prices (due to upstream taxes or emissions caps) versus household-level emissions caps, estimates per-capita emissions reductions necessary for the U.S. population to meet such targets ${ }^{1}$, and quantifies the household emissions savings of various behavioral changes and efficiency improvements.

\section{POLICY BACKGROUND}

An amendment to the international treaty on climate change, the Kyoto Protocol was ratified in 1997 and became active in 2005 (UNFCCC 2007). As an Annex I country, the U.S. would have been required to reduce its $\mathrm{CO}_{\mathrm{e}}$ emissions to 7\% below their 1990 level. In 2005, U.S. CO2

\footnotetext{
${ }^{1}$ Assuming recent population and emissions growth rates (Census 2004, EPA 2008), the reduction required by the 2012 Kyoto target for the U.S. (6.6 tons per year per person) is slightly higher than the reduction required by California’s 2020 target (6.3 tons/person/year).
} 
emissions were 8.1 billion tons, and the Kyoto Protocol would imply a cap of 6.4 billion tons by 2012 (EPA 2008). Though the U.S. originally signed the Protocol, it withdrew in March 2001, shortly after George W. Bush became president.

In February of 2002 the Bush Administration announced goals for reducing $\mathrm{CO}_{\mathrm{e}}$ emissions under the Clear Skies and Global Climate Change Initiatives. These include cutting GHG emissions intensity (tons of CO2 $2_{\mathrm{e}}$ per dollar of GDP) by 18\% over ten years (by 2012) and achieving emissions targets comparable to the Kyoto Protocol using market-based approaches. Since the plan focuses on reducing GHG intensity, total emissions could still increase. The U.S. Department of State (2007) has projected that by 2012, despite an estimated reduction in GHG intensity of $18.6 \%$, total U.S. emissions will have increased by $11 \%$ (relative to 2002 levels), to 8.5 billion tons $\mathrm{CO}_{2}$.

In early 2007, President Bush announced his Twenty in Ten plan to reduce fuel use by 20\% over ten years (White House 2007). To achieve this goal, the Energy Independence and Security Act of 2007 was passed, which includes increased production of biofuels, an increased national fuel economy standard of 35 miles per gallon (mpg) for light duty vehicles (LDV) sales by 2020, and tax incentives for those who wish to purchase hybrid vehicles (Sissine 2007).

In addition to some steps toward a federal policy, several U.S. states and cities have adopted aggressive policies to reduce GHG emissions (Martinez 2007, MEPA 2007, Clark 2007). As 34 of the world's 75 largest GHG contributors, U.S. states and their policies could have a relatively large effect on the reduction of global emissions (Gallivan et al 2007). According to the Pew Center on Global Climate Change, all 50 states have at least one policy aimed at reducing GHGs, and 18 have established targets for GHG reduction (Pew 2008).

California has been the nation's climate change policy leader. In 2005, the California Energy Action Plan II established statewide GHG reduction targets (1990 levels by 2020, and 80\% below 1990 levels by 2050), light-duty vehicle (LDV) emissions and fuel economy standards, and renewable electricity targets (CEC and CPUC 2005). California's LDV standards were adopted by several other states and would have required a 30\% GHG emission reduction in new vehicles, translating to 43 mpg fuel economy standard. However, in late December 2007, the U.S. EPA denied these states the right to set their own vehicle emission standards, claiming that the new national requirement of $35 \mathrm{mpg}$ would be more effective than a "patchwork" of state policies (Broder and Barringer 2007).

While $35 \mathrm{mpg}$ is 40 percent higher than the nation's current LDV fleet average of $25 \mathrm{mpg}$, Europe's LDV fleet already enjoys a new-sales fuel economy of 44 mpg and Japan's sales average $48 \mathrm{mpg}$ (An and Sauer 2004). The U.S. has a long way to go, though recent gas price increases (EIA 2008) may propel buyers toward 35 mpg vehicles before 2020. If every U.S. household switched to driving only hybrid cars, like the Prius (but maintained present driving distances), a 1.1 billion-ton savings in CO2 emissions would be achieved. Similarly, if every household switched to solar-powered personal vehicles, a current savings of 2.0 billion tons could be achieved. Unfortunately, those sorts of shifts are hardly likely by 2020 (to meet California's target reduction of 2.1 billion tons). In addition, reduction targets will be increasingly more difficult to meet over time, as populations grow (since per-capita reduction 
needs rise). Of course, personal transport is only part of the problem; other sources are responsible for 81\% of U.S. GHG emissions (of anthropogenic origin) (EPA 2006a) and 88\% worldwide (Wadud et al. 2007). Reductions in other sectors, as well as behaviorally-based transport reductions, are clearly needed.

\section{THE COST OF CARBON: TRAVELER RESPONSE TO PRICE CHANGES}

While many feel that the costs of climate change far outweigh the full cost of any avoidance measures (e.g., Stern 2006, Watters and Tight 2007, Anable and Shaw 2007), the marginal costs of GHG sequestration, avoidance, and removal vary widely, and the true cost of global warming is difficult to anticipate. Nevertheless, these will influence nations' emissions targets and thereby local and global carbon pricing. Presently, experts (e.g., Fischer et al. 2007, EPA 2008a, CRAI 2008, Nordhaus 2007, Metcalf 2007, and Parry and Small 2002) expect emissions removal and avoidance costs to vary between $\$ 10$ and $\$ 80$ per ton of $C O 2_{\mathrm{e}}$. This translates to just $\$ 0.13$ to $\$ 1.04$ per gallon of gasoline, quite a bit less than price shifts the nation has seen in recent years (see, e.g., EIA 2008 and Bomberg and Kockelman 2007).

As evident in recent U.S. experiences (Krauss, 2007), higher fuel prices have meant relatively little in terms of Americans' travel patterns. As experts note (e.g., Small and Van Dender, 2006 and Hughes et al., 2008), fuel is a relatively small part of vehicle ownership and use costs, and not a significant portion of annual expenditures. For example, 15,000 miles of annual vehicle use at 20 miles/gallon and \$3/gallon requires just \$2,250, or 5 percent of the average U.S. household's income (Census 2007). Moreover, U.S. land use and transit provision patterns offer relatively few easy substitutes to driving one’s car. Even a $\$ 1$ increase in U.S. gas prices (implying a tax that is roughly twice what carbon trading prices are likely to be in the near term) raises this expenditure estimate to just $\$ 3,000$ /year. Recent fuel-price elasticity estimates suggest a \$1 tax would result in near- and long-term per-capita VMT and gas-purchase reductions of just 1 to 10 percent (Hughes et al. 2008, Small and Van Dender 2006). The level of gas tax increases needed to achieve California's 2020 GHG reduction targets in the travel sector (600 million ton CO2e reduction needed in U.S., using 2005 data [EPA 2008a]) are on the order of \$5 per gallon; these kinds of numbers may quickly demobilize already burdened low-income groups.

Most people make decisions in a progressive way, adopting low-impact, short-term strategies (e.g., car pooling and traveling during off-peak hours) before making more dramatic changes (job and home locations, hybrid vehicle purchases) (Cao and Mohktarian, 2005; Bomberg and Kockelman, 2007). However, Small and Van Dender (2006) believe that "response to fuel prices has become increasingly dominated by changes in fuel efficiency rather than changes in travel”. The car serves as a status symbol for drivers of all types, including hybrid owners (e.g., Maynard et al., 2007). With personal vehicles so embedded in American culture and consumer attitudes controlling manufacturer's decisions, stricter CAFE regulations requiring more fuel efficient vehicles and environmentally oriented information campaigns may be much more effective than mode shift incentives. Moreover, given the relative (and rising) affluence of American households, taxes may not be as effective as (and may be much more harmful than) household level carbon budgets, as described below. 


\section{POLICY OPTIONS}

Many policymakers tend to favor upstream policies, including taxes on producers and cap and trade of noxious outputs. But downstream regulation deserves a close look in the case of GHG emissions. Various issues emerge in all cases, and these are discussed here.

\section{Upstream Policy Options}

Taxation is commonly evaluated as a potential policy for impacting the demand of nearly any good. As such, it is rather well understood. Its main limitations lie in determining the proper tax rate (in order to hit a target GHG reduction, in this case) and putting revenues to their highest and best use. In some contrast, cap-and-trade schemes are a more innovative and complex solution that economists and policy makers are debating for GHG reductions. (EPA 2007c, DEFRA 2007) Under a simple grandfathering approach, energy providers within a region receive allowances based on past emissions, and then trade to match needs, producing a market for emissions that new producers can buy into (with some difficulty, based on market-determined prices). Such free allocations benefit existing producers - often in a perverse fashion (with less efficient producers enjoying more initial credits) - and can restrict competition, further reducing market efficiency. Auctioning is a more likely alternative, with bid prices determining producer allowances, with revenues going to the auctioneer. Several critical decisions emerge under both cap-and-trade mechanisms: identifying participants (e.g., power generators and fuel providers, distributors of imported products, third parties working to curb emissions via alternative investments [such as home design and forest cultivation, in the U.S. and abroad]), characterizing regulated activities (e.g., heating and cooling, public and private transport, agriculture), and defining the system for administering carbon use and transactions (e.g., centralized or distributed, governmental or privately managed).

Such caps will effectively filter down as higher prices (effective taxes), and may be largely "ignored" by end users, in cases of low demand elasticity. If allowances are used (thus avoiding a great transfer of wealth from the private to the public sector), monetary benefits may accrue to relatively few entities (e.g., existing energy producers) and their shareholders. The ultimate effect of all these upstream policies could be highly regressive in nature. Nevertheless, opportunities do exist for a thoughtful distribution of revenues via income tax reductions and other income-transfer policies, to offset negative welfare effects while still preserving proper price incentives. These include various income tax reductions, increases in the Earned Income Tax Credit, and added food stamp benefits, as discussed in a recent Congressional Budget Office report (CBO 2008).

Whether taxes or cap-and-trade are pursued, higher prices will filter through to final transactions. Of course, fuel taxes already exist at the gas pump, and can be raised to reflect carbon contributions (by recognizing that $25 \mathrm{lbs}$ of CO2e are released per gallon of standard gasoline, from well to wheel, on average [EPA 2007b]). Fees could be added to airline ticket prices (based on expected aircraft fuel consumption per passenger) and utility bills (based on feedstock contributions to $\mathrm{CO} 2$ ). In theory, if one charges a tax equal to the marginal, external cost of the produced GHG, well-functioning markets should equilibrate to a social-welfare-maximizing state of (carbon) use and production (Varian, 1992; Pigou, 1954). Unfortunately, it is quite difficult to quantify the cost of global warming, and producers and consumers do not have perfect 
information, nor do they precisely maximize profits and personal utility/welfare. Moreover, related market imperfections do exist, and may impact such behaviors ${ }^{2}$. And incomes are so high in developed countries that many households may be able to avoid behavioral changes. (Fleming 2006) Unfortunately, the level of tax needed to rein in consumption by wealthier households could devastate those of lower income.

\section{The Case for Downstream Credits}

Another approach is distribution of emissions credits to end-consumers, while auditing their consumption of energy. This approach would make GHG targets, allowances and trading far more obvious to individual consumers, while addressing various equity issues inherent in alternative policies. Raux and Marlot (2005) hypothesized that such a system could be seen as an alternative to yet another tax, and thus more acceptable to the public. Moreover, since it would apply at the level of individuals (not just businesses), it may receive solid private sector support. Of course, the direct distribution of credits to end consumers addresses equity issues directly. However, the administrative burden of quantifying, tracking and reporting (and then trading) individual or household-level GHG consumption can be significant. In effect, carbon credits would represent a new, required form of currency (DEFRA 2007).

Recognizing practical limitations, such quantification and reporting would not apply to many forms of consumption (e.g., not to clothing and food); instead, it probably would emphasize home utility bills, registered-vehicle travel (via odometer readings), and air travel (via airline reporting requirements). ${ }^{3}$ While residential energy needs and personal travel are key sources (totaling 36\%) of GHG emissions, some upstream forms of regulation would still be required to hit desired targets. Nevertheless, behavioral response to downstream carbon targets is likely to be swift, more equitable, and potentially far less painful for consumers than upstream taxation (via direct taxes or cap-and-trade policies). (See, e.g., Anable and Shaw, 2007.)

There is very little research to date on the idea of consumer-level GHG emissions credits. Recently, Watters and Tight (2007) examined such opportunities and concluded that the most effective way to achieve target reductions is to combine upstream and downstream methods. They recommend upstream carbon rationing with downstream allocations, and prohibiting individuals from trading with organizations. Implementation and monitoring costs are key issues, but Watters and Tight (2007) believe that the system could be put into place within five to ten years. Interestingly, Northrop and Sassoon (2007) expect an upstream system of cap and trade policies to capture only 40 to $50 \%$ of U.S. carbon production, so approaching the policy from both ends (producers and consumers) seems wise. Recent EU research suggests that such upstream-downstream scheme combinations are feasible, and many agree that the costs of

\footnotetext{
${ }^{2}$ These include related, unpriced externalities, such as transport noise, noxious emissions, congestion and safety externalities (see, e.g., Lemp and Kockelman 2007). Under-pricing or lack of pricing on these in many nations suggests that motorized travel is still "over-consumed".

${ }^{3}$ Household reporting could occur every April, when filing personal-income tax reports, by submitting utility bill summary statements, odometer readings from inspection and maintenance program documents, and some form of information on the household's air travel. Fines would apply to those who exceed their carbon budget, reflecting an implicit market for emissions trading, while those who go under their budgets would receive tax credits (in cash form or to carry over to subsequent years, which can be very helpful when planning for long-distance travel, longterm visitors to one's home, and the like).
} 
climate change far outweigh the full cost of any avoidance measures (e.g., Stern 2006, Watters and Tight 2007, Anable and Shaw 2007).

In general, it is difficult to quantify which policy option(s) will be most effective, implementable, and acceptable. But a combination of methods appears to hold much merit. Of course, demand elasticities for gasoline appear quite low in the U.S., particularly in the near term; but our GHG emissions come from far more than the transport sector. Given the preference our decentralized systems of untethered automobile use and the energy density of petroleum, deep cuts in energy consumption may be most readily made in other forms of production and consumption, including power generation practices, food purchase decisions, home size, home design and temperature settings. The following sections describe the many elements of one's carbon "footprint", and suggest where sizable cuts in average American consumption patterns can be made, to try and achieve California targets at the level of individuals, as though under a downstream policy of carbon credits.

\section{THE SOURCES OF OUR CARBON FOOTPRINTS}

Energy is a key component of our existence. From the production and transport of foods we eat and clothes we wear, to construction and maintenance of the buildings we inhabit and propulsion of the vehicles we occupy, energy is fundamental. It is important to understand the relative and absolute contributions of our different choices.

U.S. $\mathrm{CO}_{\mathrm{e}}$ emissions per capita (average carbon footprint) were 27 tons in 2006, or $30 \%$ above CA's 2020 target (EPA 2008). These emissions come from various end-use sectors, including transport (28\%), industry (29\%), residential (17\%), commercial (17\%), and agricultural users (8\%) (EPA 2008). When electricity generation is counted separately from each end use, carbon emissions emerge in the following proportions: $34 \%$ from electricity generation, $28 \%$ from transport, $19 \%$ from industry, $8 \%$ from agriculture, $6 \%$ from commercial uses, and $5 \%$ residential uses (EPA 2008). Personal transport accounts for 19\% of total GHG emissions, or $68 \%$ of transport sector emissions, and household electricity consumption accounts for $12 \%$ of the total. Together, transport and electricity generation are responsible for $62 \%$ of total emissions. Policies to reduce $\mathrm{CO} 2$ emissions may do best to emphasize these sectors.

Improvements can be made in both supply and demand. In the transport context, for example, more fuel-efficient vehicles can be produced, public transportation could be improved, and neighborhoods can be made more pedestrian friendly and offer more local shopping. On the demand side, of course, people have to be willing to buy such cars and/or reduce their driving. Similarly, improvements could be made in electricity generation (e.g., through new windmill technologies, nuclear power investments, and carbon capture and sequestration [see, e.g., Kockelman et al. 2008]) and energy use by various products (like computers, water heating, lighting, and air-conditioning units). Of course, certain investments and design improvements can cause a household's energy expenditures to fall, encouraging a slight "rebound" in electricity use. As with gasoline, the demand for electricity has been found to be relatively inelastic ( -0.2 in the short run and -0.32 in the longer run at -0.32 [Bernstein 2006]), and the rebound effect is also marginal. (Small and Van Dender [2006] recently estimated this to be just 10 percent, in the case of gasoline.) 


\section{Reductions Needed}

The State of California is requiring that GHG emissions be reduced to 1990 emissions levels by year 2020, and $80 \%$ below 1990 levels by $2050^{4}$. If the U.S. adopts these targets, it will mean a reduction of $12 \%$ below 2006 emissions by 2020 (2.1 billion tons or $23 \%$ below projected 2020 emissions) and 82\% below 2006 emissions by 2050 (9.7 billion tons or $87 \%$ below projected 2050 emissions). Based on the current U.S. average of 27 tons of CO2 er person per year, and U.S. Census population projections (Census 2004), this implies a reduction of approximately 6 tons per person per year (or 1000 lbs per person per month) by 2020, and 23 tons per person per year (or 3800 lbs per person per month) by 2050.

Of course, households would only be responsible for a portion of the target reductions. Assuming the current distribution of GHG emissions (19\% for personal transport and 17\% for residential uses (EPA 2006a, EPA 2008)), reductions per person per year via shifts in travel decisions should be 1.2 tons (200 lbs/month) by the year 2020, and 4.4 tons (750 lbs/month) by 2050. Reductions from other household/residential sources should be 1.1 tons per person per year (180 lbs/month) by the year 2020, and 3.9 tons/year (or $650 \mathrm{lbs} / \mathrm{month}$ ) by the year 2050 . On average, reductions of 2.3 tons/month (380 lbs/month) per person by 2020 would be required to meet the target of $1240 \mathrm{lbs} / \mathrm{month} /$ person, and 8.3 tons/month (1400 lbs/month) by 2050 to meet the target of $200 \mathrm{lbs} / \mathrm{month} /$ person. Supposing that households were given carbon credits in the manner described by Watters and Tight (2007), the credits given to households to meet the 2020 target would be approximately $1240 \mathrm{lbs} / \mathrm{month} /$ person, and $200 \mathrm{lbs} / \mathrm{month} /$ person to meet the 2050 target. Households wishing to consume more energy (thus emitting more GHG) than their credits allow could purchase additional credits from households that have excess credits.

This $380 \mathrm{lbs}$ per-month per-person target is an important one to keep in mind, as we quantify the benefits of behavioral changes on the part of household (including the design of their homes and vehicles). How easy is it for American households to meet such a target? Success or failure may determine the fate of carbon reductions policies worldwide, along with the future of countless regions and their inhabitants.

\section{GHG Emissions from Transport}

The question becomes: How can we best achieve such reductions? Tallying carbon emissions in the transport sector is reasonably straightforward. Vehicle fuel is the main source of such GHG emissions, and is measured through gasoline (and diesel) sales. However, each gallon of gasoline entails wasted crude oil, refining, and transport, raising the final $\mathrm{CO} 2_{\mathrm{e}}$ tally by roughly 25 percent (to $25 \mathrm{lbs}$ of $\mathrm{CO} 2$ e per gallon of gasoline, or roughly 1 pound of $\mathrm{CO} 2$ per mile driven) (EPA 2006b). Moreover, the energy embodied in a vehicle's production contributes roughly 10 to $15 \%$ of a vehicle's lifetime carbon emissions (Carnegie Mellon University, 1998). Maintaining (and using) one's vehicle longer (or ensuring others use it for a long time) may be quite helpful in reducing one’s long-term contributions.

\footnotetext{
${ }^{4}$ U.S. CO2e emissions were 6.96 billion tons in 1990, and 7.94 billion in 2006 (EPA 2008). Projected U.S. CO2e emissions for year 2020 are 9.08 billion tons, and 11.1 billion tons in 2050 (assuming emissions growth rates from 1990 to 2006 apply).
} 
Emissions were calculated for various vehicle types and a range of vehicle miles traveled (VMT) per month, as seen in Table 1. The average VMT per month (per U.S. passenger vehicle) is just over 1,100 (NHTS 2001), and the average U.S. vehicle's fuel economy is 20.2 mpg (EPA 2006b), making for a rough CO2 emissions average of 1,360 pounds per month per vehicle. A household could save a few hundred pounds of $\mathrm{CO} 2$ emissions per month by switching from an SUV to a CUV hybrid or switching from a large/mid-sized car to a mid-sized hybrid. This may meet the 2020 target for a household's personal transport GHG emissions reductions (of 200 lbs/month/person). To meet 2050 targets (of $750 \mathrm{lb} / \mathrm{month} /$ person from transport), additional savings could come from reducing monthly VMT by 200 to 300 miles (or 6 to 10 miles/day), switching to a plug-in hybrid vehicle (soon to be available, according to Maynard 2008), or combining a vehicle switch with a switch to advanced biofuels (such as cellulosic ethanol ${ }^{5}$ ).

Air travel, another source of personal-travel emissions, was responsible for $9 \%$ of all U.S. transportation GHG emissions in 2003, with commercial air travel contributing $72 \%$ of that share (EPA 2006a). While air travel presently tends to be more efficient than driving solo (FAA 2005), actual numbers depend on aircraft occupancy, trip length, and vehicle fuel economy (which varies greatly by make and model). The average aircraft emissions intensity is $0.79 \mathrm{lbs}$ CO2e per passenger-mile (pax-mi) (FAA 2005) ${ }^{6}$, while the average American car (at 20 mpg) emits $1.3 \mathrm{lbs} /$ pax-mi when driven solo. However, as car occupancy increases, the automobile can become more efficient than flying, per passenger mile (e.g., 0.3 lbs/pax-mi with four passengers, or less for more fuel efficient autos).

Public transportation can also serve as a more efficient automobile alternative, given the right setting. Rail (heavy rail, light rail, commuter rail) is roughly 3 times more efficient than the average automobile trip (at 1.6 occupancy [NHTS 2001, Davis and Diegel 2007]). Buses, however, are not as efficient. With average bus ridership at 9 passengers per vehicle (Davis and Diegel 2007), the average automobile trip is less emitting than a bus ride of the same length. However, when considering a slightly higher bus occupancy of 11 passengers per vehicle, the two are equivalent, in terms of $\mathrm{CO} 2$ emissions. Along routes with relatively high ridership or routes utilizing alternatively fueled buses (e.g., hybrids), taking the bus instead of driving is a good way to reduce household travel emissions. This is particularly true if the car trip would have been by a single occupant. And, of course, if bus services are not being added as demand increases, there is little energy cost to adding new riders. In this way the marginal emissions rate of transit may be nearly zero (per added passenger-mile). Moreover, bus trips tend to be shorter than car trips; thus, to the extent travelers who shift modes also shorten their trip distances (and/or end up walking and biking more, in concert with their transit trips), savings can be had.

In fact, biking is the most efficient mode (Ulrich 2006) and, like the car, is “on demand”. Ondemand travel is a very attractive feature to the hundreds of millions of American who live and work in neighborhoods with relative limited transit frequency to desired destinations. A

\footnotetext{
${ }^{5}$ Cellulosic ethanol is currently being commercially produced, but in early stages of development and widespread use of this fuel is uncertain (Farrell and Sperling 2007).

${ }^{6}$ Aircraft take-offs and landings require more energy (per mile traveled) than flying at a constant altitude, so longer flights tend to produce fewer GHGs per mile than short trips.
} 
combination of bike and transit may serve the needs of many, by providing a backup mode in case of poor weather, a missed bus, imperfect transit routings, and so on.

\section{GHG Emissions from Residential Uses}

In addition to transport and various forms of embodied energy, most households use electricity continuously, to power a variety of appliances and other items. Monthly GHG savings from various appliance upgrades and usage shifts are shown in Table 4. While switching to low wattage light bulbs will certainly help households reduce $\mathrm{CO} 2{ }_{\mathrm{e}}$ emissions, shifts in heating, cooling, home design and other choices enjoy a much greater savings potential (see Figure 1).

"Phantom loads" are energy consumed by electrical devices when they are not in direct use but still plugged in, and these are estimated to account for $6 \%$ of household electricity consumption. The US Department of Energy estimates that the average US household consumes $450 \mathrm{kWh}$ per year on appliances that are turned off (DOE 2001). Plugging appliances (even clothing washers and dryers) into power strips and turning off the power strip when not in use could result in a 2,000-pound (1 ton) CO2e reduction each year, per household. Such GHG emissions estimates depend, of course, on the household's electricity grid's energy sources.

Total home cooling loads (Table 2) are most easily determined from the hours per year of air conditioner (A/C) operation. 59 percent of all U.S. homes and 90 percent of all new U.S. homes now employ central air (RECS 2005, Brown et al. 2005), versus 34\% of new homes back in 1970. The associated CO2 emissions per kilowatt-hour vary for the climate zones, and the base case assumes a 2,400+ square foot (SF) home (NAHB 2007). For a 2,000-2,500 SF home, Energy Star recommends an A/C unit with 34,000 BTU/hr capacity (Energy Star 2008). However, if the home is well shaded, one can purchase a unit with a capacity of only 30,000 $\mathrm{BTU} / \mathrm{hr}$. This is equivalent to downsizing the home to a range of 1,500-2,000 square feet. Additionally, buying a new A/C unit could reduce energy demands by a quarter, and thus result in varying degrees of $\mathrm{CO} 2$ emissions reductions. The highest cooling loads are in Climate Zone 5 (Miami, Austin, Atlanta, and Las Vegas). In this region, such simple changes can have significant energy savings. Reducing the time that an $\mathrm{A} / \mathrm{C}$ is operating during peak summer months by just one hour per day can significantly impact national CO2 emissions, in the range of 600-1,000 lbs per household per year.

Average home size in the U.S. is approximately 2400 square feet, and new-home sizes have been rising at a rate of roughly 30 SF per year over the past decade (NAHB 2007) ${ }^{7}$. For a singlefamily dwelling unit (SFDU), the total CO2 emissions per square foot per year is approximately 7.90 pounds for electricity and natural gas combined. For multi-family dwelling unit (MFDU), the average is 5.33 pounds CO2e per square foot per year, all else equal ${ }^{8}$. While home size is important, home design appears to be more important in the energy debate. Insulation thickness is considered the single most effective way to reduce a home's energy demands; and, as insulation gets thicker, home down-sizing emissions benefits fall. (Essentially, as the building envelope becomes more efficient, size is less important.) RECS regressions for non-residential

\footnotetext{
7 The average new home size in 1990 was 2050 SF; in 2004, it was 2450 SF. (NAHB 2007)

${ }^{8}$ Average SFDU size is 2540 square feet, average MFDU size is 1078 square feet. Weighted average for all US households is 2096 square feet (RECS 2001)
} 
buildings suggest that updating a building's insulation ${ }^{9}$ may save 2 to $4 \mathrm{kWh} / \mathrm{sq} \mathrm{ft}$ per year in electricity and $9 \mathrm{MBTU} / \mathrm{sqft} /$ year of natural gas. This is a combined savings of about $14 \mathrm{lbs}$ CO2e per square foot per year. For a 2,400 square foot home, this is 33,600 pounds of CO2e per year, or 2,800 pounds per month on average.

Shared walls reduce heating and cooling needs of individual units. Overall, Table 3 regression results suggest that CO2e savings in moving from a 2400 sf SFDU to a 2000 MFDU yields an annual savings of 6,846 pounds of CO2e per unit. If $1 \%$ of US households were to make such a move, the aggregate savings is estimated to be 4.3 million tons, or $0.055 \%$ of current U.S. emissions. Regression results also suggest that each added unit in an apartment building should result in a 55 lb savings of CO2e per year (per unit), after accounting for both added floors and added units. For example, households in a 5-story, 10-unit building are predicted to have energy demands that produce 328 pounds less CO2 each year than households in a 2-story, 4-unit apartment building, all else equal.

Related to all this, the U.S. share of MFDUs has been rising over the past few years to roughly 40 percent of all residential units built per year, while the share of SFDUs has fallen to roughly 55 percent, as shown in Appendix Figure C1. There may be opportunities to shift these shares much further, and increase the lifetime of MFDUs, through higher-quality construction practices.

To summarize: in the short term, substantial energy savings can be realized by adding wall and roof insulation to one's home or upgrading the air conditioning unit, especially in sunny, hot climates. Longer term savings can be achieved via downsizing and/or sharing walls, particularly via a move towards multi-unit building types. Finally, just as heating becomes more efficient as one downsizes and/or introduces shared walls, cooling load calculations yield similar results. While these calculations do not account for solar convection and radiance, heat gained through windows (a form of solar radiance) can be important in cooling load calculations, and ideally would be included in such calculations.

\section{CONCLUSIONS AND RECOMMENDATIONS}

California's emissions reduction targets are 1990 levels by 2020, and 80\% below 1990 levels by 2050. Many U.S. states and cities are taking these targets, and the issue of climate change, very seriously. This paper highlights a variety of reasonable carbon-reducing behaviors. If these and other potential behavioral adjustments can be illuminated for household members, encouraging meaningful near- and long-term behavioral changes, the planet's quest for GHG emissions reductions should be attainable.

For U.S. households, these targets translate to an estimated reduction of 380 lbs of CO2e per month per person by 2020, and 1400 lbs by 2050. As evident from values provided in Table 4, a $\mathrm{CO} 2$ emissions reduction goal of $380 \mathrm{lbs}$ per month per person could be accomplished rather readily by reducing household VMT, using a more fuel-efficient vehicle, making housing unit modifications, adopting several electricity savings suggestions, or some combination of these tactics. . For example, in the short term, if the average U.S. household reduces monthly VMT by 100 miles and reduces water heater temperature to 120 degrees Fahrenheit, it can meet CA's

\footnotetext{
${ }^{9}$ Based on 2001 data, where buildings which had replaced insulation since 1981 (20 years) saw such reductions.
} 
2020 reduction target of 380 pounds per month per person. Over a longer term, households can meet the 2050 target reduction of 1400 lbs per month per person by purchasing more fuel efficient vehicles (625 lbs per month per vehicle) and lowering heating and cooling loads (thousands lbs per month) via insulation upgrades, home size reduction, and/or sharing walls. If undertaken by all U.S. households, on average, this would allow the U.S. to meet California's 2020 and 2050 targets for household contributions to GHGs.

Reaching total 2020 and 2050 targets (not just household targets), however, will require involvement from the commercial and industrial sectors. Electrification of the vehicle fleet (via plug-in hybrids for freeway commuters), greater use of renewables (as power plant feedstocks), carbon capture and sequestration (when burning coal at power plants), smaller vehicles and homes, shared and better insulated walls, appliance upgrades, mode shifts and other behaviors are likely needed (Kockelman et al. 2008).

Appropriate policies for triggering such response across the U.S. population are less obvious. Certainly, higher CAFÉ standards are needed (e.g., $40 \mathrm{mpg}$ across all new light-duty vehicles by 2020), to ensure that the vehicle fleet heads down a path of greater efficiency. But the most important determinant of whether the U.S. and other countries can comply with emissions targets probably is end-consumer behavior. Regulations on product design, imposition of carbon budgets (with trading), and higher prices (via upstream taxes, road tolls, vehicle feebate policies, and the like) all impact choices - of dwellings, vehicles (and its occupancy), destinations, modes, fuels, foods, and other goods and services. How can we motivate change in the best directions, enhancing the health and welfare of a nation's populace while protecting the planet?

While upstream regulation of energy providers offers simpler implementation opportunities than capping emissions across final consumers, its ultimate effectiveness appears questionable when considering elasticities of demand for energy, particularly in a country as affluent as the U.S. Downstream cap-and-trade schemes require more active regulation but are arguably able to ensure more dramatic behavioral change while addressing equity implications and tax-revenue distribution issues head-on. As Watters and Tight (2007) have suggested, a combination of such policies may tap the great majority of energy users while allowing communities to more readily meet emissions targets. Individuals' formal recognition of a nation's carbon targets, via some form of personal targets, seems an appropriate policy perspective to pursue, helping ensure that consumers - not just producers - make good near- and long-term decisions.

\section{ACKNOWLEDGEMENTS}

The authors wish to thank funding sponsorship from the National Academy of Sciences (NAS), Southwest Region University Transportation Center, the Texas Department of Transportation and the National Science Foundation. We also appreciate the contributions of UT Austin's Matthew Bomberg, Dr. Michael Webber, Dr. Jeffrey Siegel, and Annette Perrone along with valuable suggestions by Drs. Phil Patterson (DOE) and Danilo Santini (Argonne National Laboratories). Several pieces of this work are included in a larger report, commissioned by the 
NAS's Committee for the Study on the Relationships Among Development Patterns, VMT, and Energy Conservation.

\section{REFERENCES}

An, F, Sauer, A. (2004) Comparison of Passenger Vehicle Fuel Economy and Greenhouse Gas Emission Standards around the World. Pew Center on Global Climate Change. Accessed from http://www.pewclimate.org/docUploads/Fuel\%20Economy\%20and\%20GHG\%20Standards_010 605_110719.pdf on July 14, 2008.

Anable, J., J. Shaw (2007). Priorities, policies, and (time)scales: the delivery of emissions reductions in the UK transport sector. Area 39 (4) 443-457.

American Society of Heating, Refrigerating, and Air-Conditioning Engineers (ASHRAE) (2001). ASHRAE Handbook: 2001 Fundamentals. Atlanta, Georgia: American Society of Heating, Refrigerating, and Air-Conditioning Engineers, Inc.

Bernstein, M., Griffin, J. (2006). Regional Differences in the Price Elasticity of Demand for Energy. National Renewable Energy Laboratory. Accessed from http://www.nrel.gov/docs/fy06osti/39512.pdf on July 19, 2007.

Bomberg, Matthew and Kara Kockelman (2007). Traveler Response to the 2005 Gas Price Spike. Meeting Compendium of the Transportation Research Board's 86th Annual Meeting, Washington, DC, January 2007. Accessed from http://www.ce.utexas.edu/prof/kockelman/public_html/TRB07GasPriceResponses.pdf on April 7, 2008.

Broder, J., Barringer, F. (2007). E.P.A. Says 17 States Can’t Set Emission Rules. New York Times. Accessed from http://www.nytimes.com/2007/12/20/washington/20epa.html on June 17, 2008.

Bush, G. (2002). President Announces Clear Skies and Global Climate Change Initiatives. Presidential remarks, delivered at The White House. Accessed from http://www.whitehouse.gov/news/releases/2002/02/20020214-5.html on July 19, 2007.

Cao, X. , Mokhtarian, P.L., (2005). How do individuals adapt their personal travel? Objective and subjective influences on the consideration of travel-related strategies for San Francisco Bay Area commuters. Transport Policy 12 (4) 291-302.

Carnegie Mellon University (1998). Automobiles: Manufacture vs. Use. Institute for Lifecycle Environmental Assessment. Accessed from http://iere.org/ILEA/lcas/macleanlave1998.html on July 18, 2007.

CBO (2008) Options for Offsetting the Economic Impact on Low- and Moderate-Income Households of a Cap-and-Trade Program for Carbon Dioxide Emissions. Congressional Budget Office response to Senator Jeff Bingham's information request. Accessed from http://www.cbo.gov/ftpdocs/93xx/doc9319/06-17-ClimateChangeCosts.pdf on July 15, 2008.

Census (2004). Interim Projections by Age, Sex, Race, and Hispanic Origin. U.S. Census Bureau. Accessed from http://www.census.gov/ipc/www/usinterimproj/ on March 13, 2008.

Census (2007). USA QuickFacts. U.S. Census Bureau. Accessed from http://quickfacts.census.gov/qfd/states/00000.html on July 21, 2007. 
Clark, A. (2007). West Coast Leaders Pledge to Fight Climate Change, Together. The Associated Press State and Local Wire. April 6, 2007.

CEC and CPUC (2005). California Energy Action Plan II. State of California Energy Commission and Public Utilities Commission. Accessed from

http://www.energy.ca.gov/energy_action_plan/2005-09-21_EAP2_FINAL.PDF on April 7, 2008.

CRAI (2008). Economic Modeling of the Lieberman-Warner Bill: S. 2191 as Reported by Senate EPW. Charles River Associates, International. January.

Davis, S., Diegel, S. (2007). Transportation Energy Data Book: Edition 26. Center for Transportation Analysis: Energy Division. Accessed from http://cta.ornl.gov/data/index.shtml on November 23, 2007.

DEFRA (2007). UK Emissions Trading Scheme. Department for Environment, Food and Rural Affairs. Accessed from http://www.defra.gov.uk/environment/climatechange/trading/uk/index.htm on July 19, 2007.

DEFRA (2007). European Union Emissions Trading Scheme. Department for Environment, Food and Rural Affairs. Accessed from http://www.defra.gov.uk/environment/climatechange/trading/eu/index.htm on July 21, 2007. DEFRA (2008) UK Climate Change Sustainable Development Indicator: 2006 Greenhouse Gas Emissions, Final Figures. Department of Environmental, Food and Rural Affairs. Accessed from http://www.defra.gov.uk/environment/statistics/globatmos/download/ghg_ns_20080131.pdf on July 28, 2008.

DOE (2001) Energy Efficient Appliances. U.S. Department of Energy. Accessed from http://www1.eere.energy.gov/buildings/appliance_standards/pdfs/26468.pdf on December 1, 2008

EIA (2001). Figure 1: Percentage of Total Electricity Consumption in U.S. Housing Units, 2001. Energy Information Administration. Accessed from http://www.eia.doe.gov/emeu/recs/recs2001/enduse2001/figure1.html on July 19, 2007.

EIA (2008) Gasoline and Diesel Fuel Update. Energy Information Administration. Accessed from http://tonto.eia.doe.gov/oog/info/gdu/gasdiesel.asp on July 14, 2008.

EPA (2006a). Greenhouse Gas Emissions from the U.S. Transportation Sector: 1990-2003. Environmental Protection Agency. Accessed from http://epa.gov/otaq/climate/420r06003.pdf on July 23, 2007.

EPA (2006b) Light-Duty Automotive Technology and Fuel Economy Trends: 1975 Through 2006. Environmental Protection Agency. Accessed from http://www.epa.gov/otaq/fetrends.htm on July 25, 2007.

EPA (2007a). Light-Duty Automotive Technology and Fuel Economy Trends: 1975 Through 2007. Environmental Protection Agency. Accessed from http://www.epa.gov/otaq/fetrends.htm on July 28, 2008.

EPA (2007b). Regulatory Impact Analysis: Renewable Fuel Standard Program, Chapter 6 Lifecycle Impacts on Fossil Energy and Greenhouse Gases. Environmental Protection Agency. Accessed from http://www.epa.gov/otaq/renewablefuels/420r07004chap6.pdf on July 24, 2007. 
EPA (2007c). Cap and Trade: Acid Rain Program Basics. Environmental Protection Agency. Accessed from http://www.epa.gov/airmarkets/cap-trade/docs/arbasics.pdf on July 21, 2007.

EPA (2007d) eGrid2006 Version 2.1, Year 2004 Summary Tables. U.S. Environmental Protection Agency. Accessed from http://www.epa.gov/cleanenergy/energyresources/egrid/index.html on July 29, 2008.

EPA (2008a). EPA Analysis of the Lieberman-Warner Climate Security Act of 2008, S. 2191 in 110th Congress. U.S. Environmental Protection Agency, Washington, D.C.

EPA (2008b). Draft Inventory of U.S. Greenhouse Gas Emissions and Sinks: 1990-2006. U.S. Environmental Protection Agency. Accessed from http://epa.gov/climatechange/emissions/usinventoryreport.html on March 11, 2008.

Farrell, A., Sperling, D. (2007) A Low-Carbon Fuel Standard for California: Part 1 - Technical Analysis. University of California, Berkeley and University of California, Davis. Accessed from http://www.eners.ch/plateforme/medias/uc_2007a.pdf on July 30, 2008.

FAA (2005) Aviation and Emissions: A Primer. Federal Aviation Administration, Office of Environment and Energy. Accessed from http://www.faa.gov/regulations_policies/policy_guidance/envir_policy/media/AEPRIMER.pdf on June 25, 2008.

Fischer, C., W. Harrington, and I.W.H. Parry (2007) Should Automobile Fuel Economy Standards be Tightened? The Energy Journal, 28 (4), 1-29.

Fleming, D. (2006). Tradable Energy Quotas (TEQs): Pathway for a Phased Energy Descent? presented at the Colloquium Transport, Energy and Greenhouse Gases: Will Rationing be Necessary? 4-5 December 2006 Lyon, France.

Gallivan, F., Ang-Olson, J., Schroeer, W. (2007). Innovations in State-Led Action to Reduce Greenhouse Gas Emissions from Transportation: The State Climate Action Plan. Presented at the TRB $87^{\text {th }}$ Annual Meeting.

Hughes, Jonathan E., Christopher R. Knittel, and Daniel Sperling (2008). Evidence of a Shift in the Short-run Price Elasticity of Gasoline Demand. Energy Journal 29 (1): 113-134.

IPCC (2007). Working Group III contribution to the Intergovernmental Panel on Climate Change Fourth Assessment Report Climate Change 2007: Mitigation of Climate Change, Summary for Policymakers. Accessed from http://www.mnp.nl/ipcc/docs/FAR/SPM_\%20WGIII_rev5.pdf on July 24, 2007.

Kockelman, K., M. Bomberg, M. Thompson and C. Whitehead (2008). GHG Emissions Control Options: Opportunities for Conservation. Paper commissioned by the National Academy of Sciences' Committee for the Study on the Relationships Among Development Patterns, VMT, and Energy Conservation.

Krauss, C. (2007, March 30). Drivers Shrug as Gasoline Prices Soar. New York Times. Accessed from http://www.nytimes.com/2007/03/30/business/30gas.html?_r=1\&oref=slogin on July 19, 2007.

Lemp, J., Kockelman, K. (2006). Quantifying the External Costs of Vehicle Use: Evidence from the Top Selling Passenger Vehicle Models. Submitted for presentation to the 87th Annual Meeting of the Transportation Research Board, in Washington D.C. Accessed from 
http://www.ce.utexas.edu/prof/kockelman/public_html/TRB08VehicleExternalities.pdf on July 23, 2007.

Martinez, M. (2007). California Emissions Law Inspires Illinois. Chicago Tribune, February 12. Maynard, M. (2008) Toyota Will Offer a Plug-in Hybrid Vehicle by 2010. The New York Times, January 14.

Maynard, M., Bunkley, N., Chapman, M. (2007). Toyota Hybrid Makes a Statement, and That Sells. The New York Times, July 4.

MEPA (2007). “MEPA Greenhouse Gas Emissions Policy and Protocol.” Massachusetts Environmental Policy Act. Accessed from http://www.mass.gov/envir/mepa/pdffiles/misc/ghgemissionspolicy.pdf on June 5, 2007.

Metcalf, G. (2007). Corporate Tax Reform: Paying the Bills with a Carbon Tax. Public Finance Review. 35 (3) 440-459.

MSN (2007). America's Best Sellers of 2006. Microsoft Network. Accessed from http://autos.msn.com/advice/article.aspx?contentid=4023925 on October 23rd, 2007.

NAHB (2007). Housing Facts, Figures and Trends. National Association of Home Builders. Accessed from http://www.nahb.org on March 5, 2008

NHTS (2001). Do More Vehicles Make More Miles? A Snapshot Analysis of the National Household Travel Survey 2001. National Household Travel Survey. Accessed from http://nhts.ornl.gov/2001/presentations/vehicleMiles/VehicleMiles.pdf on July 25, 2007.

Nordhaus, W. (2007). To Tax or Not to Tax: Alternative Approaches to Slowing Global Warming. Review of Environmental Economics and Policy. 1(1):26-44.

Northrop, M. and D. Sassoon (2007). Cap and Trade and More. Environmental Finance June.

Parry, I., Small, K. (2002). Does Britain or the United States Have the Right Gasoline Tax? Resources for the Future. Washington, D.C.

Pew Center on Global Climate Change (2008). Climate Change Initiatives and Programs in the States. Arlington, VA. Accessed from http://www.pewclimate.org/docUploads/States\%20table\%203\%2027\%2008.pdf on July 28, 2008.

Pigou, A.C. (1954). Some Aspects of the Welfare State. Diogenes 7 (6) 1-11.

Raux C, and Marlot G. (2005). A System of Tradable CO2 Permits Applied to Fuel Consumption by Motorists, Transport Policy, Vol 12, No 3, pp. 255-265.

RECS (2001) 2001 Residential Energy Consumption Survey data. U.S. Energy Information Administration. Washington, D.C. Available at http://www.eia.doe.gov/emeu/recs/.

Sissine, F. (2007). Energy Independence and Security Act of 2007: A Summary of Major Provisions. Congressional Research Service. Accessed from http://energy.senate.gov/public/_files/RL342941.pdf on April 7, 2008.

Small, K., Van Dender, K. (2006). Fuel Efficiency and Motor Vehicle Travel: the Declining Rebound Effect. Department of Economics, University of California, Irvine. Accessed from http://www.economics.uci.edu/docs/2005-06/Small-03.pdf on July 9, 2008. 
Stern, N. (2006). Stern Review on the Economics of Climate Change. HM Treasury. Accessed from http://www.hm-

treasury.gov.uk/independent_reviews/stern_review_economics_climate_change/stern_review_re port.cfm on February 2, 2008.

Tomlinson, J. (2002). All Pumped Up. Home Energy On-Line Magazine. Nov/Dec. pp. 30-35

Ulrich, K. (2006) The Environmental Paradox of Bicycling. University of Pennsylvania, The Wharton School. Accessed from http://opim.wharton.upenn.edu/ ulrich/documents/ulrichcycling-enviro-jul06.pdf on June 26th, 2008.

U.S. Department of State (2007). Fourth Climate Action Report to the UN Framework

Convention on Climate Change. Accessed from http://www.state.gov/g/oes/rls/rpts/car/ on July 19, 2007.

U.S. EPA (2003). eGRID 2006, Version 2.1. Washington, DC: U.S. Environmental Protection Agency. Accessed from http://www.epa.gov/egrid on April 7, 2008.

UNFCCC (2007). Kyoto Protocol Reference Manual on Accounting of Emissions and Assigned Amounts. United Nations Framework Convention on Climate Change. Accessed from http://unfccc.int/files/national_reports/accounting_reporting_and_review_under_the_kyoto_prot ocol/application/pdf/rm_final.pdf in June 2007.

Varian, H. (1992). Microeconomic Analysis, Third Edition. New York: W. W. Norton and Company.

Wadud, Z., R. Noland, D. Graham (2007). Equity Implications of Tradable Carbon Permits for the Personal Transport Sector. Proceedings of the 86th Annual Meeting of the Transportation Research Board, Washington D.C. January.

Watters, H., M. Tight. (2007). Designing an Emissions Trading Scheme Suitable for Surface Transport. Institute for Transport Studies, University of Leeds. Accessed from http://www.cfit.gov.uk/docs/2007/climatechange/pdf/2007climatechange-ets.pdf in May 2007

White House (2007). Fact Sheet: Twenty in Ten: Reducing America’s Dependence on Oil. http://www.whitehouse.gov/news/releases/2007/03/20070320-2.html on April 7, 2008. 


\section{LIST OF FIGURES}

Figure 1. Household Electricity Consumption

\section{LIST OF TABLES}

Table 1. Expected Monthly CO2 Emissions by Vehicle Type and Miles Driven

Table 2. Cooling Loads for Single Family Homes in 20 Cities

Table 3. Annual $\mathrm{CO} 2$ e Savings for Home Change Scenarios, versus from Standard Home (pounds per year $\mathrm{CO} 2_{\mathrm{e}}$ )

Table 4. Potential Strategies for Carbon Savings 


\section{Household Electricity Consumption}

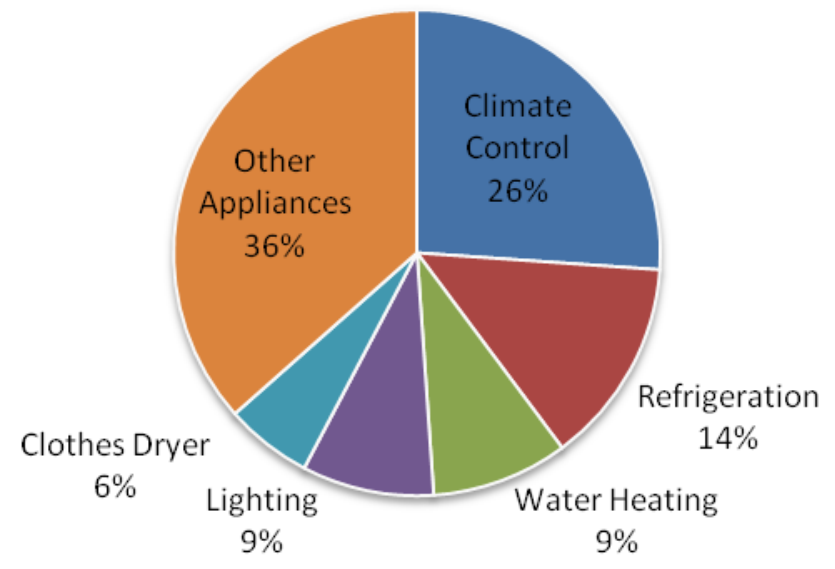

Figure 1. Household Electricity Consumption (Source: Adapted from EIA 2001, Figure 1)

Table 1. Expected Monthly CO2 Emissions by Vehicle Type and Miles Driven

\begin{tabular}{|c|c|c|c|c|c|}
\hline \multicolumn{3}{|c|}{ Vehicle Characteristics } & \multicolumn{3}{|c|}{$\begin{array}{l}\text { CO2 Emissions (lbs/month) } \\
\text { given VMT (mi/month) }\end{array}$} \\
\hline Vehicle Class & Make/Model & $\begin{array}{l}\text { Combined } \\
\text { MPG }\end{array}$ & $\begin{array}{c}800 \\
\text { VMT } \\
(9600 \\
\mathrm{mi} / \mathrm{yr})\end{array}$ & $\begin{array}{c}1,000 \\
\text { VMT } \\
(12,000 \\
\mathrm{mi} / \mathrm{yr})\end{array}$ & $\begin{array}{c}1,200 \\
\text { VMT } \\
(14,400 \\
\mathrm{mi} / \mathrm{yr})\end{array}$ \\
\hline Midsize Hybrid & Toyota Prius Hybrid & 46 & 435 & 543 & 652 \\
\hline Compact Hybrid & Honda Civic Hybrid & 42 & 476 & 595 & 714 \\
\hline CUV Hybrid & Ford Escape Hybrid & 31 & 645 & 806 & 968 \\
\hline Compact & Honda Civic (1.8L) & 29 & 690 & 862 & 1034 \\
\hline Compact & Toyota Corolla (1.8L) & 29 & 690 & 862 & 1034 \\
\hline Compact & Chevrolet Cobalt (2.2L) & 26 & 769 & 962 & 1154 \\
\hline Midsize & Nissan Altima (2.5L) & 26 & 769 & 962 & 1154 \\
\hline Midsize & Toyota Camry (2.4L) & 25 & 800 & 1000 & 1200 \\
\hline Large & Honda Accord (2.4L) & 24 & 833 & 1042 & 1250 \\
\hline Large & Chevrolet Impala (3.9L) & 21 & 952 & 1190 & 1429 \\
\hline Pickup Truck & Chevrolet Silverado (4WD, 4.3L) & 15 & 1333 & 1667 & 2000 \\
\hline Pickup Truck & Dodge Ram (4WD, 4.7L) & 15 & 1333 & 1667 & 2000 \\
\hline Pickup Truck & Ford F-150 (4WD, 4.6L) & 14 & 1429 & 1786 & 2143 \\
\hline
\end{tabular}

Notes: Vehicles were chosen based on highest sellers in 2006 (MSN 2007). Fuel economy comes from www.fueleconomy.gov and assumes 2008 model year and automatic transmission. Numbers in parentheses define size of engine, in liters (L), and whether the vehicle is a four-wheel-drive variety (4WD). 
Table 2. Cooling Load Reduction for Single Family Homes in 20 Cities

\begin{tabular}{|c|c|c|c|c|c|c|c|c|c|}
\hline \multirow{3}{*}{$\begin{array}{c} \\
\text { Climate } \\
\text { Zone }\end{array}$} & \multirow[b]{3}{*}{ City } & \multirow[b]{3}{*}{ CDD } & \multirow[b]{3}{*}{$\begin{array}{c}\mathrm{lb} \\
\mathrm{CO} 2 / \mathrm{kWh}\end{array}$} & & & \multicolumn{4}{|c|}{ Annual CO2e savings } \\
\hline & & & & \multicolumn{2}{|c|}{ AC Use } & \multirow{2}{*}{$\begin{array}{c}\text { (1) } \\
\text { Update } \\
\text { Unit }\end{array}$} & \multirow{2}{*}{$\begin{array}{c}(2) \\
\text { Downsize } \\
\text { Home }\end{array}$} & \multirow[b]{2}{*}{ (1) \& (2) } & \multirow{2}{*}{$\begin{array}{c}\text { (3) } \\
\text { Less } 1 \\
\text { hr/day }\end{array}$} \\
\hline & & & & hours/day & day/yr & & & & \\
\hline \multirow{4}{*}{ Zone 1} & Spokane, WA & 684 & 0.23 & 6 & 52 & 72 & 32 & 96 & 46 \\
\hline & Billings, MT & 882 & 1.98 & 6 & 65 & 772 & 348 & 1029 & 493 \\
\hline & Portland, MA & 521 & 0.91 & 2 & 90 & 164 & 74 & 218 & 314 \\
\hline & Green Bay, WI & 665 & 1.71 & 4 & 59 & 403 & 182 & 538 & 387 \\
\hline \multirow{4}{*}{ Zone 2} & Harrisburg, PA & 1225 & 1.13 & 6 & 84 & 569 & 257 & 759 & 364 \\
\hline & Denver, CO & 948 & 1.98 & 7 & 90 & 1247 & 563 & 1663 & 683 \\
\hline & Chicago, IL & 1030 & 1.71 & 6 & 71 & 728 & 329 & 971 & 465 \\
\hline & Detroit, MI & 796 & 1.71 & 4 & 78 & 533 & 241 & 711 & 511 \\
\hline \multirow{4}{*}{ Zone 3} & Baltimore, MD & 1377 & 1.39 & 12 & 49 & 817 & 369 & 1090 & 261 \\
\hline & Seattle, WA & 306 & 0.23 & 2 & 53 & 24 & 11 & 33 & 47 \\
\hline & New York, NY & 1162 & 1.13 & 6 & 72 & 488 & 220 & 651 & 312 \\
\hline & Kansas City, MO & 1714 & 1.9 & 12 & 67 & 1527 & 689 & 2037 & 488 \\
\hline \multirow{4}{*}{ Zone 4} & Los Angeles, CA & 654 & 0.48 & 9 & 14 & 60 & 27 & 81 & 26 \\
\hline & Atlanta, GA & 1784 & 1.69 & 12 & 67 & 1359 & 613 & 1811 & 434 \\
\hline & Sacramento, CA & 1388 & 0.48 & 10 & 72 & 346 & 156 & 461 & 132 \\
\hline & Raleigh-Durham, NC & 1573 & 1.39 & 12 & 56 & 934 & 421 & 1245 & 298 \\
\hline \multirow{4}{*}{ Zone 5} & Miami, FL & 4431 & 1.39 & 11 & 185 & 2828 & 1276 & 3771 & 986 \\
\hline & Austin, TX & 3228 & 1.63 & 13 & 106 & 2246 & 1013 & 2994 & 662 \\
\hline & Charleston, SC & 2200 & 1.39 & 12 & 79 & 1317 & 594 & 1757 & 421 \\
\hline & Las Vegas, NV & 3489 & 1.46 & 12 & 120 & 2102 & 948 & 2803 & 672 \\
\hline
\end{tabular}

Notes: The carbon intensity of electricity generation varies by region/city, due to different feedstocks. The base case assumes a central AC unit operates at the given hours/day for the specified number of days per year. This assumes a single family home of 2000-2500 square feet, requiring an AC unit with 34,000 Btu/hr capacity, and an AC unit installed in 1986 with an efficiency of 8.87. As of 2001, 85\% of homes had central air conditioning. Scenario 1 calculates the same AC use, but with a newer, more efficient AC unit, one installed in 2003 or later. Scenario 2 demonstrates the expected change if the same household moved to a smaller home - from 2000-2500 SF to 1500-2000 SF. This requires a unit with a capacity of only 30,000 Btu/hr. Scenario 3 calculates the annual kWh of energy used if a household reduces AC operation by one hour each day (from days per year that ASHRAE assumes households in these cities use AC) 
Table 3. Summary of Linear Regression Coefficients from Residential Energy Consumption Survey (RECS)

\begin{tabular}{|c|c|c|c|}
\hline & & $\begin{array}{l}\text { Single Family } \\
\text { Dwelling Unit }\end{array}$ & $\begin{array}{l}\text { Multifamily } \\
\text { Dwelling Unit }\end{array}$ \\
\hline \multirow{9}{*}{ 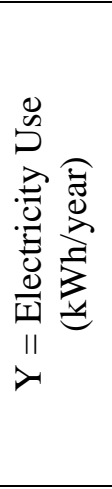 } & Household Size & 991 & 611 \\
\hline & HH Members >65 & 164 & -327 \\
\hline & CDD & 2.11 & 1.49 \\
\hline & Total Square Footage & 0.80 & 0.75 \\
\hline & Number of Floors & -33.88 & -29.10 \\
\hline & Number of Apartments & $\mathrm{n} / \mathrm{a}$ & -4.411 \\
\hline & Town Indicator & 1665 & 763 \\
\hline & Rural Indicator & 854 & 26 \\
\hline & Suburban Indicator & 4084 & 2350 \\
\hline \multirow{10}{*}{ 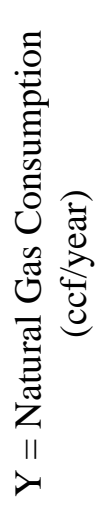 } & Household Size & 27 & 20 \\
\hline & HH Members > 65 & -3.02 & 34 \\
\hline & HDD & 0.049 & 0.022 \\
\hline & Programmable Thermostat & -12 & 2.5 \\
\hline & Total Square Footage & 0.073 & 0.027 \\
\hline & Number of Floors & 7.48 & 1.26 \\
\hline & Number of Apartments & $\mathrm{n} / \mathrm{a}$ & -0.795 \\
\hline & Town Indicator & -152 & -20.8 \\
\hline & Rural Indicator & -86 & 22 \\
\hline & Suburban Indicator & -498 & -168 \\
\hline
\end{tabular}

Note: Parameter estimates/slope values come from ordinary least squares regression results of RECS 2001 data, adapted from Kockelman et al. (2008). Other model results: Electricity in SFDUs: $n=2,935, R^{2}=0.411$, constant $=$ 8101; natural gas in SFDUs: $n=2,935, R^{2}=0.266$, constant $=181.6$; electricity in MFDUs: $n=1,136, R^{2}=0.314$, constant $=6380$; natural gas in MFDUs: $n=692, \mathrm{R}^{2}=0.143$, constant $=31.3$. 
Table 4. Potential Strategies for Carbon Savings

\begin{tabular}{|c|c|c|c|}
\hline Strategy & $\begin{array}{c}\text { Lbs CO2e } \\
\text { Saved Per } \\
\text { Month }\end{array}$ & Strategy & $\begin{array}{c}\text { Lbs CO2e } \\
\text { Saved Per } \\
\text { Month }\end{array}$ \\
\hline Personal Transport & & Residential & \\
\hline Reduce VMT by $100 \mathrm{mi} / \mathrm{month}$ & & $\begin{array}{l}\text { Appliance Upgrades \& Behavioral } \\
\text { Shifts }\end{array}$ & \\
\hline 35 mpg vehicle & 71 & Conv. Water Heater to Heat Pump & 337 \\
\hline $30 \mathrm{mpg}$ & 83 & Clothes Washer: Hot to Cold water & 173 \\
\hline $25 \mathrm{mpg}$ & 100 & Water Heater Temp: 140 to $120^{\circ} \mathrm{F}$ & 137 \\
\hline $20 \mathrm{mpg}$ & 125 & $\begin{array}{l}\text { Computer: Sleep mode while not in } \\
\text { use }\end{array}$ & 103 \\
\hline $15 \mathrm{mpg}$ & 167 & Eliminate Phantom loads & 37 \\
\hline Bike $100 \mathrm{mi} /$ month (in lieu of driving) & 122 & $\begin{array}{l}\text { Reduce AC operation by one hour } \\
\text { (hot climates) }\end{array}$ & 67 \\
\hline Bike $10 \mathrm{mi} /$ month (in lieu of driving) & 12.2 & & \\
\hline & & Housing Unit Design & \\
\hline Increase fuel economy from: & & $\begin{array}{l}2400 \text { sq ft SFDU to } 2400 \mathrm{sq} f t \\
\text { MFDU }\end{array}$ & 570 \\
\hline $\begin{array}{l}20 \text { to } 40 \text { mpg (driving } 1000 \\
\text { mi/month) }\end{array}$ & 625 & $\begin{array}{l}2400 \text { sq ft SFDU to } 2000 \text { sq ft } \\
\text { SFDU }\end{array}$ & 64 \\
\hline 15 to $20 \mathrm{mpg}$ & 417 & $\begin{array}{l}\text { Update central AC unit (varies by } \\
\text { use and climate) }\end{array}$ & $30-160$ \\
\hline 20 to $25 \mathrm{mpg}$ & 250 & Replace old insulation & 2,800 \\
\hline 25 to $30 \mathrm{mpg}$ & 167 & & \\
\hline 30 to $35 \mathrm{mpg}$ & 119 & & \\
\hline 35 to $40 \mathrm{mpg}$ & 89 & & \\
\hline Eliminate 1,000 mi flight that year & 79 & & \\
\hline $\begin{array}{l}\text { Drive 1,000 mi in lieu of flying that } \\
\text { year }\end{array}$ & 40 & & \\
\hline
\end{tabular}

Note: Year 2020 target is expected to be 380 lbs per person per month (to address home and personal travel emissions share of total GHG emissions).

Assumptions:

1. Mode switch to biking assumes traveler had been driving a $20 \mathrm{mpg}$ vehicle with 1 passenger, and zero GHG emissions from biking.

2. The energy required to produce the calories used while biking was $675 \mathrm{BTU} / \mathrm{mi}$ (Ulrich 2006). This energy use emitted 0.000393 lbs CO2e/BTU (average U.S. electricity grid; EPA 2007d).

3. Mode switch, from flying to driving assumes a $20 \mathrm{mpg}$ vehicle.

4. Flying is assumed responsible for $0.79 \mathrm{lbs} \mathrm{CO} /$ pax-mi (according to FAA 2005).

5. Phantom loads of $450 \mathrm{kWh} /$ year

6. AC unit updated from SEER 8.87 to 12; Operating times from Table 2, adapted from ASHRAE (2001)

7. Old insulation uses non-residential RECS data (Kockelman et al. 2008)

8. Energy intensity conversions for homes: $1.34 \mathrm{lbs} \mathrm{CO} 2 \mathrm{e} / \mathrm{kWh}, 11.7 \mathrm{lbs} \mathrm{CO} e / \mathrm{ccf}$ 